\title{
Ultrahang-elasztográfia alkalmazásának lehetőségei a szülészet-nőgyógyászatban
}

\author{
Kozma Bence dr. ${ }^{1}$ - Pákozdy Krisztina dr. ${ }^{1}$ - Lampé Rudolf dr. ${ }^{1}$ \\ Berényi Ervin dr. ${ }^{2}$. Takács Péter dr. ${ }^{3}$ \\ ${ }^{1}$ Debreceni Egyetem, Általános Orvostudományi Kar, Szülészeti és Nőgyógyászati Intézet, Debrecen \\ ${ }^{2}$ Debreceni Egyetem, Általános Orvostudományi Kar, Orvosi Képalkotó Intézet, Debrecen \\ ${ }^{3}$ Eastern Virginia Medical School, Department of Obstetrics and Gynecology, \\ Division of Female Pelvic Medicine and Reconstructive Surgery, Norfolk, VA, United States of America
}

\begin{abstract}
Az ultrahang-elasztográfia az elmúlt évek során egyre növekvő figyelmet kapott a lágyszövetek elaszticitásának vizsgálatában. A módszer használatát az teszi szükségessé, hogy egyes, a mechanikai tulajdonságaikban különböző szövetek hasonló echogenitásúak lehetnek, valamint hogy egy adott szövet megváltozott struktúrája vagy mechanikai tulajdonsága nem minden esetben jár együtt a szövet hagyományos ultrahangképének megváltozásával. Az elmúlt évtizedben a deformációs és a nyírási ultrahang-elasztográfia vált széles körben elérhetővé. Ezen új képalkotási technika egyre nagyobb szerepet tölt be a szülészeti-nőgyógyászati ultrahang-diagnosztikában is. A nőgyógyászatban szerephez juthat az endometriosis és az adenomyosis kimutatásában, valamint a benignus és a malignus cervicalis és ovarialis képletek elkülönítésében. A nőgyógyászathoz hasonlóan a szülészetben is jelentős változást hozhat az ultrahang-elasztográfia: alkalmas lehet a szülésindukció sikerességének, a koraszülés bekövetkezésének és a praeeclampsia kialakulásának elörejelzésére.
\end{abstract}

Orv Hetil. 2021; 162(18): 690-695.

Kulcsszavak: ultrahang-elasztográfia, deformációs elasztográfia, nyírási elasztográfia, szöveti keménység

\section{Application of ultrasound elastography in obstetrics and gynecology}

\begin{abstract}
Ultrasound elastography has received significant attention for the assessment and measurement of soft tissue elastic properties in recent years. The advantage of ultrasound elastography lies in the fact that two different tissues can share similar echogenicities but may have other mechanical properties or, on the contrary, mechanical abnormalities of a designated tissue do not necessarily go hand in hand with an altered appearance on a conventional ultrasound image. In the last decade, strain and shear-wave elasticity imaging methods have become the most widely available among commercial ultrasound equipments. The importance of this new method expands rapidly also in the field of obstetrics and gynecology. Ultrasound elastography has a promising role in the diagnosis of endometriosis and adenomyosis and helps to differentiate benign and malignant cervical and ovarian lesions. The use in the prediction of the outcome of labor induction and preterm birth, and in the evaluation of preeclampsia are emerging.
\end{abstract}

Keywords: ultrasound elastography, strain elastography, shear-wave elastography, tissue stiffness

Kozma B, Pákozdy K, Lampé R, Berényi E, Takács P. [Application of ultrasound elastography in obstetrics and gynecology]. Orv Hetil. 2021; 162(18): 690-695.

(Beérkezett: 2020. október 24.; elfogadva: 2020. november 19.)

\section{Rövidítések}

CT = (computed tomography) számítógépes tomográfia; MRI $=($ magnetic resonance imaging $)$ mágnesesrezonancia-képalkotás; $\mathrm{SE}=$ strain (deformációs) elasztográfia; SWE = shear-wave (nyírási) elasztográfia; UHE = ultrahang-elasztográfia
Az orvostudomány a szövetek keménységének tapintás útján történő vizsgálatát évezredek óta használja a betegségek diagnosztizálására, míg az orvosi képalkotás bevezetését hagyományosan Wilhelm Conrad Röntgen 1895. évi kísérletéhez kötjük. Ismert tény, hogy a kóros szöve- 
tek elasztikus tulajdonságai általában eltérést mutatnak az egészséges szövetekéhez képest, a szöveti keménység képalkotás útján történő megjelenítése mégis egészen az 1990-es évekig váratott magára. Elsőként Ophir és mtsai írtak az ultrahangalapú elasztográfiáról: új módszerük kvantitatívan ábrázolta a szövetek elaszticitásának mértékét lágyszövetekben [1]. Úttörő munkája alapján a módszer atyjának dr. Jonathan Ophirt tekinthetjük. A módszer alapja a Hooke-törvény, mely kimondja, hogy egy rugalmas test alakváltozása arányos azzal az eróvel, mely az alakváltozást okozza. Az elmúlt harminc évben a technológia jelentős fejlődésen ment keresztül, és számos közlemény született ezen új képalkotó módszer felhasználásainak lehetőségeirôl.

A humán orvosi felhasználás céljából kereskedelmi forgalomban kapható, az ultrahang-elasztográfia (UHE) lehetőségével felszerelt készülékekben jelenleg két különböző típusú elasztográfiás módszer érhető el: a strain és a shear-wave elasztográfia [2]. A strain, azaz deformációs elasztográfia (SE) egy olyan kvalitatív képalkotó technika, amely az egyes szövetek egymáshoz viszonyított relatív keménységét jeleníti meg. A shear-wave, azaz nyírási elasztográfia (SWE) ezzel szemben kvantitatív metódusként, a szövetek keménységének becsült értékét fejezi ki a szöveten áthaladó nyíróhullámok sebességének segítségével méter/másodpercben vagy kPa-ban, a Young-modulusból (rugalmassági modulus) származtatott értékkel [3]. A két módszer eltérő fizikai alapjai eltérő klinikai felhasználási területeket is tesznek lehetővé, bár általánosan elfogadott, hogy megfelelő kivitelezéssel és az artefaktumok minimalizálásával egy adott szövet vizsgálata során igen jól korrelálnak egymással, jóllehet általában a SE részletgazdagabb térbeli felbontást képes létrehozni, míg a SWE kontrasztosabb képet jelenít meg.

A különböző fizikai alapokon nyugvó UHE-módszerek közös jellemzője, hogy a képalkotás során a transzducerre megfelelő mértékű nyomást fejtünk ki, a készülék pedig a nyomás kifejtése előtti és alatti képen hasonlítja össze a vizsgált szövet elmozdulását. Az elmozdulást vagy deformációt, azaz a két kép különbségét színskálán kódolja és helypontosan rávetíti a hagyományos B-módú ultrahangképre. Ezen elterjedt megjelenítési mód előnye egyrészt a gyorsaságában rejlik, hiszen a hagyományos és az elasztográfiás felvétel egy időben történik meg, másrészt az egymásra vetített képek lehetőséget adnak a vizsgált szövet anatómiai helyzetének pontos leírására, így a létrehozott kép megfelelő interpretációjára is.

Az UHE-vizsgálatok esetében is igaz, hogy a vizsgálat kezdeti lépése a hagyományos B-módú ultrahangvizsgálat elvégzése, melynek elsődleges célja az anatómiai struktúrák, így a célterület pontos meghatározása. Ezt követően a készülék elasztográfia-üzemmódját aktiválva - a color-Doppler-üzemmódhoz hasonlóan - egy változtatható méretú és elhelyezkedésú ablakban, színkódolt formában jelenik meg az elasztográfiás kép. Fantomon végzett vizsgálatok alapján a legjobb képfeldolgozás akkor jön létre, ha az elasztográfiás ablak a kép 20-50\%-át foglalja el [4]. A szerzők véleménye szerint jelentősen könnyíti a vizsgálatot, valamint a mentett képek utólagos értékelését, ha a vizsgálat kettéosztott képernyőn történik: a hagyományos B-módú kép mellett egy időben látható a B-módú képre szemitranszparensen vetített elasztográfiás ablak is. SE esetében a legjobb jel-zaj viszony a transzducer fel-le irányú mozgatásával érhető el. Az ideális kompresszió mértékét nyomásjelző skála is segíti, mely - a legtöbb készülék esetén - zöld színnel jelzi az ideális nyomási tartomány elérését. SWE során kiemelt figyelmet kell fordítani arra, hogy a vizsgált területre kifejtett kompresszió mértéke a lehető legkisebb legyen.

Az UHE a klinikai gyakorlatban a leginkább a máj, az emlö, a pajzsmirigy, a prosztata, a vesék, a nyirokcsomók és a szívizom vizsgálata céljából terjedt el, de számos esetben orvostudományi kutatómódszerként is olvashatunk róla $[5,6]$. A máj vizsgálata tekintetében említésre méltó, hogy az elasztográfia mint vizsgálómódszer szerepel a hepatitis B- és D-vírus-fertőzés diagnosztikájával foglalkozó hazai konszenzusajánlásban, valamint egyik alapvető vizsgálóeljárása a májat érintő klinikai kutatásoknak [7,8]. Szintén hazai közlemények húzzák alá az UHE lehetséges szerepét az emlőrák diagnosztikájában, de bőrgyógyászati és colorectalis alkalmazásáról is olvashatók folyóiratcikkek [9-11]. Az UHE egyre növekvő számú közleménnyel alátámasztva mindinkább szerepet kap a szülészeti-nőgyógyászati betegségek és állapotok diagnosztizálásában is.

\section{Ultrahang-elasztográfia a nőgyógyászatban}

Mint a képalkotó módszereknél általában, az elasztográfiás vizsgálatok során is alapvető követelmény a vizsgált szerv vagy szövet egészséges állapotának ismerete. Az élettani uterus első részletes UHE-s leírására csak 2019 ben került sor Manchanda és mtsai által [12]. A SWEmódszerrel készült vizsgálat meghatározta az endometrium, a myometrium és a cervix elasztikus értékeinek normáltartományát.

Az uterus UHE-vizsgálatainak leírása során a szakirodalom külön figyelmet szentel a cervixnek, terhes és nem terhes állapotának egyaránt. A rendelkezésre álló kevés adat alapján valószínúsíthető, hogy a cervix UHE során mért elasztikus tulajdonságai nem függnek az életkortól [13], vizsgálata ugyanakkor számos limitáló tényezőbe ütközik. A nem homogén szöveti összetétel, valamint a cervix szöveteinek összesített akusztikai csillapítása - mely több mint kétszerese a májénak $\left(1,3-2,0 \mathrm{~dB} \mathrm{~cm}^{-1}\right)-$ miatt az ultrahangnyaláb mélyebb rétegekbe történő behatolása akadályozott, ami nagyban gátolja a vizsgálat pontos elvégzését [14]. A vizsgálat standardizálását nehezíti, hogy a cervix mellső és hátsó ajka között szöveti különbségek lehetnek, valamint hogy egyénenként változó konzisztenciájú szövetként a vizsgálat során a transzducerre kifejtett nyomás sem határozható meg egységes módon. O'Hara és mtsai közleményükben javasolják a cervix vizsgálata során a transzducerre kifejtett nyomás mérséklését, 
csökkentve ezáltal a prestressz miatti artefaktumok megjelenésének lehetőségét, továbbá a vizsgálat szempontjából ideális régiónak a mellső ajkat tekintik, lehetőség szerint annak horizontális helyzetében [15]. A cervix UHE-vizsgálatának fontos klinikai felhasználási területe lehet a benignus és a malignus cervicalis laesiók elkülönítése. Lu és mtsai cikkükben rámutatnak, hogy bár ebből a szempontból az UHE igen ígéretes, a vizsgálatok szubjektív értékelése, az esetlegesen jelen lévő kalcifikálódott cervicalis myomák vagy haemorrhagiás necrosisok jelenléte a módszer mindennapi klinikai rutinba történő bevezetését nagymértékben akadályozza [16].

Az UHE tekintetében a méhtest jóindulatú elváltozásai közül a leginkább a leiomyomát és az adenomyosist dolgozták fel. A kezdeti közlések már megállapították, hogy mindkét elváltozás jól vizsgálható UHE segítségével [17, 18], ugyanakkor Stoelinga és mtsai 2014-ben írták le elsőként szisztematikusan a leiomyoma és az adenomyosis elasztográfiai megjelenését [19]. Vizsgálatukban az UHE megfelelően szenzitívnek és specifikusnak bizonyult az elváltozások diagnosztizálására, valamint kitünő egyezést mutatott a vizsgálat résztvevőin elvégzett MRI-k eredményeivel. Mindhárom idézett kutatást SE felhasználásával végezték. Ugyanakkor egy, a közelmúltban megjelent tanulmány szerint SWE segítségével nem lehetett megfelelő mértékben elkülöníteni a leiomyomát és az adenomyosist [20]. A vizsgálat azonban azt is demonstrálta, hogy a myometriumban mért nyírási hullámsebesség szignifikánsan eltér a leiomyomát vagy adenomyosist tartalmazó és az egészséges uterusok között, mely megfigyelésnek az ezen jóindulatú elváltozásokhoz köthető fájdalom és a megváltozott spermiumtranszport miatt kialakuló szubfertilitás tekintetében fontos klinikai haszna lehet.

Az UHE mind nagyobb szerephez jut a petefészek kórállapotainak vizsgálatában is. Mivel a legtöbb petefészek-laesio tartalmaz solid és cysticus részeket is, a malignus és a nem malignus kórállapotok elkülönítése a különböző képalkotó modalitásokkal számos akadályba ütközik. Míg Herek és mtsai vizsgálata a jó- és rosszindulatú eltérések különbözőségeire helyezi a hangsúlyt [21], addig Xie és mtsai kutatása alapján az UHE szerepet kaphat az alacsony és a magas gradusú serosus ovariumtumorok elkülönítésében: az alacsony gradusú tumorok elaszticitása elmarad a magasakéitól [22]. Egy 2014-ben megjelent, kis esetszámú tanulmány szerint az UHE szenzitívebb a magas gradusú serosus petefészektumorok neoadjuváns kemoterápiára adott válaszának vizsgálatában, mint a CT vagy az MRI [23].

Az endometriosis képalkotó eszközökkel történő pontos leírása számos esetben nehézségbe ütközik. SWEmódszerrel azonban jól meghatározható a nyíróhullám terjedési sebessége, mely endometriomában és bevérzett petefészekcystákban mérve szignifikáns különbséget mutat [24]. Az endometriosis különböző megjelenési formáit tekintve a mélyen infiltráló forma igen nagy klinikai relevanciával bír, ugyanakkor ennek a pontos kivizsgálása a legnehezebb. A medencefenék izomzatát érintő endo- metriosisban megváltozik a medencefenék izmainak elaszticitása, mely változás UHE során kvantitatívan is mérhető [25]. Ehhez hasonlóan a Douglas-üreg elaszticitása is csökken a hegképződés és a kötőszöveti remodelling miatt, ami szintén jól ábrázolható elasztogrammon [26]. Az UHE segítséget nyújthat az endometriosis olyan, nem szokványos megjelenési formáinak differenciáldiagnózisában is, mint a hasfali endometriosis vagy a császármetszés hegének endometriosisa [27, 28].

A medencefenék funkcionális anatómiájának és biomechanikájának megértésében a képalkotó technikák közül az UHE-nak igen fontos szerepe lehet. Vizeletincontinentiában szenvedő nőket vizsgálva Kreutzkamp és mtsai bizonyították, hogy azon incontinens nók paraurethralis szövetének elaszticitása módosul, akikben jelen van a húgycső fokozott mobilitása, az egészséges kontrollcsoporthoz képest [29]. Több közlemény is foglalkozik a medencefenék izomelemeinek UHE-módszerrel történő vizsgálatával: Gachon és mtsai a musculus (m.) levator ani [30], Aljuraifani és mtsai pedig a harántcsíkolt urogenitalis sphincter esetében bizonyították, hogy a képletek jól vizsgálhatók elasztográfiával [31]. A kismedencei süllyedéses kórképek kialakulásában a medencefenéki izomzat sérüléseinek vagy strukturális változásainak kulcsszerepük van. A hüvelyi szülés során bekövetkező traumás elváltozások ultrahangalapú vizsgálatában vezető szerepet játszik a háromdimenziós tomografikus képalkotás [32], azonban Masslo és mtsai munkájából kitünik, hogy az eddig alkalmazott módszereken felül az UHE a sérülések mellett képes más, funkcióvesztéssel járó állapotok feltárására is, mint a hegképződés vagy a hipokontraktilitás [33]. Xie és mtsai közlése alapján a kismedencei süllyedéses kórképek kialakulásának rizikófaktora lehet a $\mathrm{m}$. levator ani elaszticitásának csökkenése, majd később ugyanezen szerzők bizonyították, hogy az izom elaszticitása mérhetően javul kismedencei torna végzésével $[34,35]$. Eredményeik arra engednek következtetni, hogy a hagyományos képalkotó módszerekkel sérülésmentesnek látszó levator izomzat funkciója kismedencei torna végzésével javítható.

Pákozdy és mtsai közelmúltban megjelent közleménye első alkalommal számol be UHE-val Magyarországon végzett nőgyógyászati klinikai vizsgálatról, elsőként írva az irodalomban is a hüvelyfal SE-vizsgálatáról [36]. Kutatásukban az UHE mint a hüvelyfali atrophia kimutatására alkalmas új módszer jelenik meg: az atrophiás hüvelyfal szignifikánsan rigidebb, míg a nem atrophiás hüvelyfal jobb elaszticitású (1. ábra).

\section{Ultrahang-elasztográfia a szülészetben}

Annak ellenére, hogy az UHE újabb képalkotó módszernek tekinthető, várandós nőkön történő alkalmazásával számos kutatás foglalkozik, mely tanulmányok tárgya leggyakrabban a méhszáj vagy a méhlepény vizsgálata egészséges terhességben és különböző terhességi kórállapotokban. 


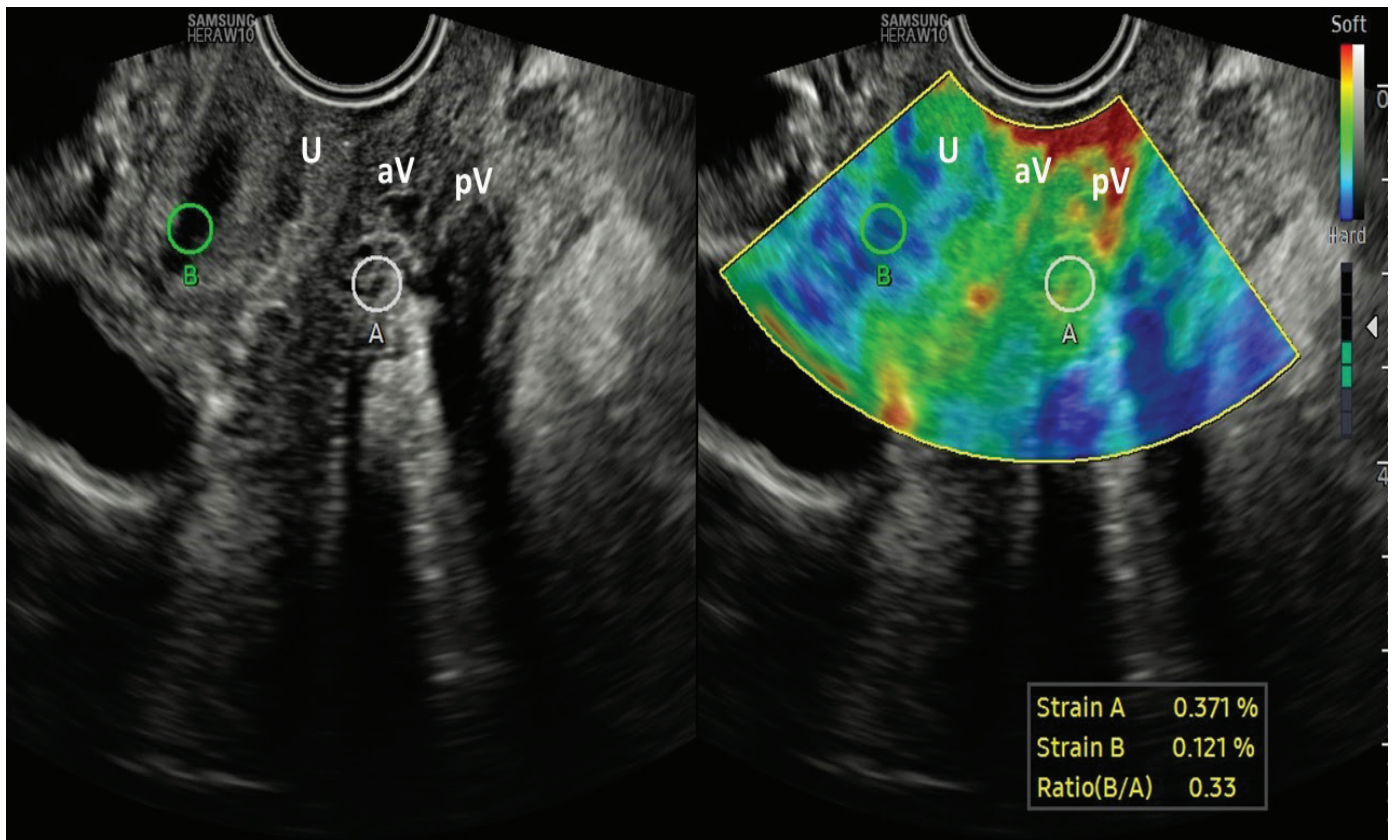

1. ábra

A hüvelyfal ultrahangképe strain (deformációs) elasztográfiás üzemmódban. A húgycsőben lévő vizelet folyadékként nem nyomható össze, így az itt elhelyezett „B” ROI alacsony elaszticitású (kék), a hüvelyfal területén elhelyezett „A” ROI közepes elaszticitást igazol (zöld) (a szerző saját felvétele)

$\mathrm{aV}=$ mellső hüvelyfal; $\mathrm{pV}=$ hátsó hüvelyfal; $\mathrm{ROI}=$ (region of interest $)$ vizsgálati régió; $\mathrm{U}=$ húgycső

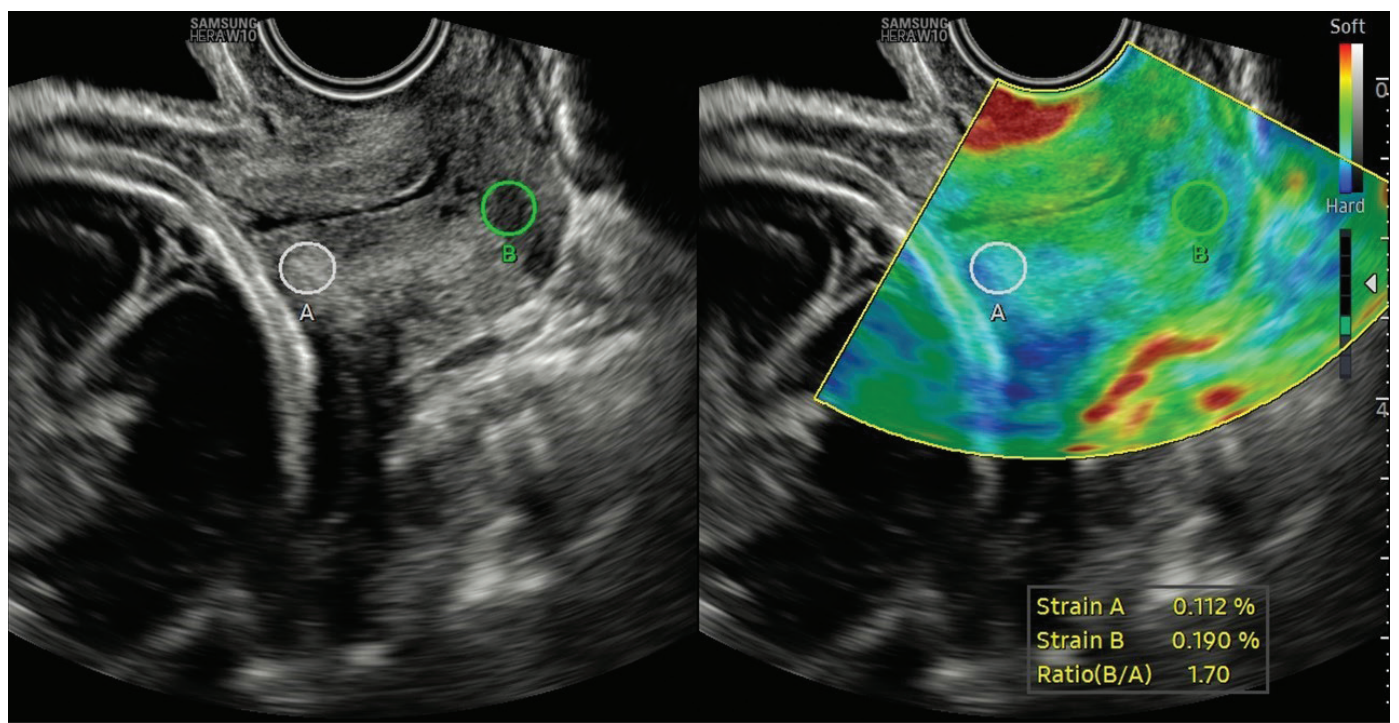

2. ábra

A cervix ultrahangképe strain (deformációs) elasztográfiás üzemmódban a 26. gestatiós hétben lévő gravida esetében. Az endocervix területén elhelyezett „A” ROI keményebb, míg az ectocervix területén elhelyezett „B” ROI puhább szövetet igazol (a szerző saját felvétele)

$\mathrm{ROI}=($ region of interest $)$ vizsgálati régió

Tanulmányok alapján a koraszülések előrejelzésében is szerephez juthat az UHE. Du és mtsai eset-kontroll vizsgálata demonstrálta, hogy a cervix keménysége objektíven és kvantitatívan vizsgálható a terhesség során [37]. Fontos megállapításuk, hogy egy tünetmentes, a koraszülés tekintetében alacsony rizikójúnak tekinthető populációban a második, illetve harmadik trimeszterben a belső méhszáj területén végzett UHE nagyobb eséllyel jelzi előre a koraszülést, mint a jelenleg általánosan használt cervixhosszúság-mérés. Más szerzők mértéktartób- ban fogalmaznak abban a tekintetben, hogy az UHE nagyobb szenzitivitással bír-e, mint a cervixhosszúságmérés. Ugyanakkor a koraszülés előrejelzésével kapcsolatban megjelent, az UHE-módszer felhasználását bemutató közlemények közös jellemzője, hogy a jövőben rendkívül ajánlatos lenne a cervixhosszúság-mérést és az UHE-t kombináló módszer létrehozása, mely - a rendelkezésre álló adatok alapján - nagyobb érzékenységgel jelezné előre a spontán koraszüléseket, mint az egyes módszerek külön-külön [38, 39] (2. ábra). 
A szülészeti hivatás számára továbbra is jelentős kihívás a szülésindukció sikerességi rátájának további emelése. A hagyományosan az indukció sikerességének előrejelzésére is szolgáló Bishop-pontszámnak azonban a szubjektív és a prediktív értéke is viszonylag alacsony [40], ezért mind nagyobb az igény az objektív és magasabb prediktív értékkel bíró módszerekre. Londero és mtsai összefoglaló közleményt és metaanalízist jelentettek meg az UHEnek a szülésindukció-sikeresség előrejelzésében betöltött szerepéről [41]. 4 közlemény 323 esetéből levont következtetésük alapján a kisszámú és igen heterogén vizsgálatok ellenére az UHE rendkívül ígéretes módszer lehet ezen a területen. Eredményeik alapján a méhszáj UHEvizsgálata a méhszáj ultrahangvizsgálata során mért cervixhosszal kombinálva megbízhatóbb módszer lehet, mint a Bishop-pontszám önmagában.

A placenta UHE-vizsgálata a különböző terhességi kórállapotokban jut szerephez. A megjelent vizsgálatok döntő többsége SWE-módszerrel vizsgálja a méhlepényt. Cimsit és mtsai egy, a második trimeszterben végzett vizsgálat során szignifikáns különbséget találtak az egészséges és a praeeclampsiával szövődött terhességekben a placenta szonoelasztikus tulajdonságai között [42]. Karaman és mtsai a harmadik trimeszterben acoustic radiation force impulse elastosonography technikát alkalmazva mérték a méhlepény keménységét egészséges és praeeclampsiával szövődött terhességekben [43]. Eredményeik alapján a praeeclampsia a placenta elaszticitásának csökkenésével jár együtt. A fenti vizsgálatok alapján az UHE szerephez juthat a praeeclampsia korai előrejelzésében. Szintén SWE-módszerrel hasonlították össze és találtak szignifikáns különbséget az egészséges és a gestatiós diabetes mellitusszal szövődött terhességekben a placenták elaszticitása között Yuksel és mtsai [44]. Közleményük alapján az UHE segíthet megérteni a placentának a gestatiós diabetes mellitus során kialakuló morfológiai változásait, de a jövőben akár hozzájárulhat a gestatiós cukorbetegség menedzsmentjéhez is.

\section{Következtetés}

Az ultrahang-elasztográfia egyesíti a hagyományos ultrahangvizsgálatok előnyeit, úgymint az elérhetőség, a noninvazivitás és a 'real-time' (valós idejű) képalkotás, a szövetek keménységének megjelenítésével és annak számszerúsítésével. Az első, elasztográfia-üzemmóddal bíró ultrahangkészülékek 2003-ban kerültek forgalomba, ma már azonban a legtöbb gyártó számos készüléke rendelkezik ezzel az üzemmóddal [2]. Az UHE a nőgyógyászat számos területén alkalmazható: szerephez juthat a benignus és a malignus cervicalis laesiók elkülönítésében, a leiomyomák és az adenomyosis diagnosztikájában, a petefészek kórállapotainak differenciáldiagnosztikájában, az endometriosis kimutatásában, a medencefenék funkcionális anatómiájának és biomechanikájának megértésében és a hüvelyfal atrophiájának igazolásában is. A nőgyógyászathoz hasonlóan a szülészet- ben is jelentős változást hozhat az UHE: szerepe lehet a szülésindukció sikerességének, a koraszülésnek, a praeeclampsiának és a gestatiós diabetes mellitusnak az előrejelzésében és azok menedzsmentjében. Az UHE korszerü és fejlődő technológia, melynek klinikai felhasználási lehetőségei jelenleg is intenzíven zajló kutatások tárgyai. Hangsúlyozandó, hogy az UHE jelenleg mint kiegészítő módszer jelenik meg a megfelelően gondos, kétdimenziós ultrahangvizsgálat elvégzése után, a diagnózist megerősítő vagy differenciáldiagnosztikai céllal, valamint olyan esetekben, amikor kifejezetten a vizsgált szövet elasztikus tulajdonságai vannak a vizsgálat fókuszában. Az elasztográfia során nyert információkat együttesen kezelve vagy akár a hagyományos ultrahangvizsgálat által szolgáltatott adatokkal fuzionálva, az ultrahangképalkotás ezen új módszere a jövőben hasonlóan fontos lehet a mindennapi döntéshozatal során, mint ahogyan a Doppler-vizsgálat annak elmaradhatatlan részévé vált.

Anyagi támogatás: A közlemény megírása, illetve a kapcsolódó kutatómunka anyagi támogatásban nem részesült.

Szerzôi munkamegosztás: K. B.: Adatgyüjtés, a közlemény megírása. P. K.: Adatgyưjtés, a közlemény javítása. L. R., B. E.: A közlemény javítása, kiegészítése. T. P.: Adatgyưjités, a közlemény javítása, kiegészítése, végleges korrektúra. A cikk végleges változatát valamennyi szerző elolvasta és jóváhagyta.

Érdekeltségek: A szerzőknek nincsenek érdekeltségeik.

\section{Irodalom}

[1] Ophir J, Céspedes I, Ponnekanti H, et al. Elastography: a quantitative method for imaging the elasticity of biological tissues. Ultrason Imaging 1991; 13: 111-134.

[2] Shiina T, Nightingale KR, Palmeri ML, et al. WFUMB guidelines and recommendations for clinical use of ultrasound elastography: Part 1: basic principles and terminology. Ultrasound Med Biol. 2015; 41: 1126-1147.

[3] Dietrich CF, Barr RG, Farrokh A, et al. Strain elastography how to do it? Ultrasound Int Open 2017; 3: E137-E149.

[4] Havre RF, Elde E, Gilja OH, et al. Freehand real-time elastography: impact of scanning parameters on image quality and in vitro intra- and interobserver validations. Ultrasound Med Biol. 2008; 34: 1638-1650.

[5] Sigrist RM, Liau J, Kaffas AE, et al. Ultrasound elastography: review of techniques and clinical applications. Theranostics

[6] Priksz D, Bombicz M, Varga B, et al. Upregulation of myocardial and vascular phosphodiesterase $9 \mathrm{~A}$ in a model of atherosclerotic cardiovascular disease. Int J Mol Sci. 2018; 19: 2882.

[7] Horváth G, Gerlei Z, Gervain J, et al. Diagnosis and treatment of chronic hepatitis B and D. National consensus guideline in Hungary from 22 September 2017. [A hepatitis B- és D-vírusfertőzés diagnosztikája, antivirális kezelése. Magyar konszenzusajánlás. Érvényes: 2017. szeptember 22-től.] Orv Hetil. 2018; 159(Suppl 1): 24-37. [Hungarian]

[8] Budai BK, Tóth A, Borsos P, et al. Three-dimensional CT texture analysis of anatomic liver segments can differentiate between 
low-grade and high-grade fibrosis. BMC Med Imaging 2020; 20: 108 .

[9] Bidlek M, Kovács E, Fehér K, et al. New trends and novel possibilities in the diagnostic imaging of breast cancer. [Újdonságok, új lehetőségek az emlődaganatok képalkotó diagnosztikájában.] Magy Onkol. 2015; 59: 44-55. [Hungarian]

[10] Vas K, Besenyi Z, Urbán S, et al. Efficacy and safety of long pulse 1064 and $2940 \mathrm{~nm}$ lasers in noninvasive lipolysis and skin tightening. J Biophotonics 2019; 12: e201900083.

[11] Bor R, Fábián A, Szepes Z. Role of ultrasound in colorectal diseases. World J Gastroenterol. 2016; 22: 9477-9487.

[12] Manchanda S, Vora Z, Sharma R, et al. Quantitative sonoelastographic assessment of the normal uterus using shear wave elas tography: an initial experience. J Ultrasound Med. 2019; 38: 3183-3189.

[13] Thomas A, Kümmel S, Gemeinhardt O, et al. Real-time sonoelastography of the cervix: tissue elasticity of the normal and abnormal cervix. Acad Radiol. 2007; 14: 193-200.

[14] Palmeri ML, Feltovich H, Homyk AD, et al. Evaluating the feasibility of acoustic radiation force impulse shear wave elasticity imaging of the uterine cervix with an intracavity array: a simulation study. IEEE Trans Ultrason Ferroelectr Freq Control 2013; 60: 2053-2064.

[15] O'Hara S, Zelesco M, Sun Z. Shear wave elastography on the uterine cervix: technical development for the transvaginal approach. J Ultrasound Med. 2019; 38: 1049-1060.

[16] Lu R, Xiao Y, Liu M, et al. Ultrasound elastography in the differential diagnosis of benign and malignant cervical lesions. J Ultrasound Med. 2014; 33: 667-671.

[17] Ami O, Lamazou F, Mabille M, et al. Real-time transvaginal elastosonography of uterine fibroids. Ultrasound Obstet Gynecol. 2009; 34: 486-488

[18] Tessarolo M, Bonino L, Camanni M, et al. Elastosonography: a possible new tool for diagnosis of adenomyosis? Eur Radiol 2011; 21: 1546-1552.

[19] Stoelinga B, Hehenkamp WJ, Brölmann HA, et al. Real-time elastography for assessment of uterine disorders. Ultrasound Obstet Gynecol. 2014; 43: 218-226.

[20] Zhang M, Wasnik AP, Masch WR, et al. Transvaginal ultrasound shear wave elastography for the evaluation of benign uterine pathologies: a prospective pilot study. J Ultrasound Med. 2019; 38: 149-155.

[21] Herek D, Karabulut A, Agladioglu K. Usefulness of transabdominal real-time sonoelastography in the evaluation of ovarian lesions: preliminary results. Br J Radiol. 2016; 89: 20160173.

[22] Xie M, Zhang X, Zhan J, et al. Application of real-time ultrasound elastography for discrimination of low- and high-grade serous ovarian carcinoma. J Ultrasound Med. 2013; 32: $257-$ 262.

[23] Xie M, Zhang X, Jia Z, et al. Elastography, a sensitive tool for the evaluation of neoadjuvant chemotherapy in patients with highgrade serous ovarian carcinoma. Oncol Lett. 2014; 8: 1652 1656.

[24] Batur A, Yavuz A, Ozgokce M, et al. The utility of ultrasound elastography in differentiation of endometriomas and hemorrhagic ovarian cysts. J Med Ultrason (2001). 2016; 43: 395400 .

[25] Xie M, Feng Y, Zhang X, et al. Evaluation of pelvic floor muscle by transperineal elastography in patients with deep infiltrating endometriosis: preliminary observation. J Med Ultrason (2001). 2019; 46: 123-128.

[26] Schiffmann ML, Schäfer SD, Schüring AN, et al. Importance of transvaginal ultrasound applying elastography for identifying deep infiltrating endometriosis. A feasibility study. Ultraschall Med. 2014; 35: 561-565.
[27] Xie M, Zhang X, Zhan J, et al. Potential role of strain elastography for detection of the extent of large-scar endometriosis. J Ultrasound Med. 2013; 32: 1635-1642.

[28] Wozniak S, Czuczwar P, Szkodziak P, et al. Elastography improves the accuracy of ultrasound in the preoperative assessment of abdominal wall endometriosis. Ultraschall Med. 2015; 36: 623-629.

[29] Kreutzkamp JM, Schäfer SD, Amler S, et al. Strain elastography as a new method for assessing pelvic floor biomechanics. Ultrasound Med Biol. 2017; 43: 868-872.

[30] Gachon B, Nordez A, Pierre F, et al. In vivo assessment of the levator ani muscles using shear wave elastography: a feasibility study in women. Int Urogynecol J. 2019; 30: 1179-1186.

[31] Aljuraifani R, Stafford RE, Hug F, et al. Female striated urogenital sphincter contraction measured by shear wave elastography during pelvic floor muscle activation: proof of concept and validation. Neurourol Urodyn. 2018; 37: 206-212.

[32] Kozma B, Larson K, Scott L, et al. Association between pelvic organ prolapse types and levator-urethra gap as measured by $3 \mathrm{D}$ transperineal ultrasound. J Ultrasound Med. 2018; 37: 28492854.

[33] Masslo K, Möllers M, de Murcia KO, et al. New method for assessment of levator avulsion injury: a comparative elastography study. J Ultrasound Med. 2019; 38: 1301-1307.

[34] Xie M, Zhang X, Liu J, et al. Evaluation of levator ani with no defect on elastography in women with POP. Int J Clin Exp Med. 2015; 8: 10204-10212.

[35] Xie M, Zhang X, Zhang X, et al. Can we evaluate the levator ani after Kegel exercise in women with pelvic organ prolapse by transperineal elastography? A preliminary study. J Med Ultrason (2001). 2018; 45: 437-441

[36] Pákozdy K, Sipos AG, Bombicz M, et al. Vaginal elasticity is significantly decreased in vaginal atrophy: a strain elastography study. Menopause 2020; 27: 1420-1424.

[37] Du L, Zhang LH, Zheng Q, et al. Evaluation of cervical elastography for prediction of spontaneous preterm birth in low-risk women: a prospective study. J Ultrasound Med. 2020; 39: 705-713.

[38] Hernandez-Andrade E, Garcia M, Ahn H, et al. Strain at the internal cervical os assessed with quasi-static elastography is associated with the risk of spontaneous preterm delivery at $\leq 34$ weeks of gestation. J Perinat Med. 2015; 43: 657-666.

[39] Oturina V, Hammer K, Möllers M, et al. Assessment of cervical elastography strain pattern and its association with preterm birth. J Perinat Med. 2017; 45: 925-932.

[40] Kolkman DG, Verhoeven CJ, Brinkhorst SJ, et al. The Bishop score as a predictor of labor induction success: a systematic review. Am J Perinatol. 2013; 30: 625-630.

[41] Londero AP, Schmitz R, Bertozzi S, et al. Diagnostic accuracy of cervical elastography in predicting labor induction success: a systematic review and meta-analysis. J Perinat Med. 2016; 44: 167178.

[42] Cimsit C, Yoldemir T, Akpinar IN. Shear wave elastography in placental dysfunction: comparison of elasticity values in normal and preeclamptic pregnancies in the second trimester. J Ultrasound Med. 2015; 34: 151-159.

[43] Karaman E, Arslan H, Cetin O, et al. Comparison of placental elasticity in normal and pre-eclamptic pregnant women by acoustic radiation force impulse elastosonography. J Obstet Gynaecol Res. 2016; 42: 1464-1470.

[44] Yuksel MA, Kilic F, Kayadibi Y, et al. Shear wave elastography of the placenta in patients with gestational diabetes mellitus. J Obstet Gynaecol. 2016; 36: 585-588.

(Kozma Bence dr., Debrecen, Nagyerdei krt. 98., 4032 e-mail: bence.kozma@med.unideb.hu) 